\title{
An Application Of Stock-Trak In 'Investments': What Common Mistakes Do Students Make While Studying Socioeconomic Processes?
}

https://doi.org/10.21272/sec.4(1).5-16.2020

Halil D. Kaya, ORCID: https://orcid.org/0000-0002-7535-9857

$\mathrm{PhD}$, Professor of Finance, Department of Accounting and Finance, College of Business and Technology, Northeastern State University, USA

Julia S. Kwok, ORCID: https://orcid.org/0000-0002-1321-2200

PhD, Professor of Finance, Department of Accounting and Finance, College of Business and Technology, Northeastern State University, USA

\begin{abstract}
The main purpose of this study is to review practical experience and provide guidance on the use of StockTrak software (trading virtual assets of various types of investment assets) by students to make investment decisions under uncertainty. The article uses such scientific methods of analysis as analysis, synthesis, comparison, abstraction and modeling. The information base for the study is students enrolled in bachelor's degree programs in economics at Northeastern State University (USA). Based on the analysis of students' reports for the period 2014-2017, it is established that the most common mistakes in the study of socioeconomic processes include the neglect of transaction costs and the non-accounting of dividends in the calculations. For the most part, students have difficulty calculating financial ratios correctly because they are not sufficiently familiar with the procedure for acquiring investment assets using margin, and are unable to determine the initial amount of investment when purchasing assets using margin and have difficulty separating the profit option. Previous studies of methods and models of mastering knowledge of investment activities show that gamification of the educational process, an interactive form of practical exercises helps to improve the quality of communication of learning subjects, improve the overall level of learning effectiveness, as well as better mastering of knowledge through their practical use in the beginning. mode and subsequently in further professional activity. The results of the study may be useful to teachers in the financial and economic disciplines in terms of a detailed analysis of the major difficulties encountered by students in using the program and avoiding these errors in their activities.
\end{abstract}

Keywords: investments, mutual fund, options, portfolio, stock, Stock-Trak.

JEL Classification A20, A22.

This work is licensed under a Creative Commons Attribution 4.0 International License.

Cite as: Halil D. Kaya, Julia S. Kwok (2020). An Application Of Stock-Trak In 'Investments': What Common Mistakes Do Students Make While Studying Socioeconomic Processes? SocioEconomic Challenges, 4(1), 516. https://doi.org/10.21272/sec.4(1).5-16.2020.

(C) The Authors, 2020. This article is published with open access at Sumy State University.

\section{Introduction}

In this study, we present an application of 'Stock-Trak' in an undergraduate-level investments class. This assignment is used to help students learn more about the different types of investments including stocks, mutual funds, index funds, T-bills, bonds, and options. Students practice 'trading' these different assets and then they report these trades as well as their returns. After collecting their final reports, we analyzed the types of mistakes that they make. 
In this assignment, students are asked to pick ten stocks, four mutual funds, two market index funds, one international market index fund, a Treasury bill, three Treasury/corporate/municipal notes or bonds, two calls, and two puts listed on the New York Stock Exchange, the American Exchange, NASDAQ or any other international exchange outside the U.S. They are required to take long and short positions in stocks and to purchase at least two stocks on margin. When making their selections, they are encouraged to use Research Insight, other databases presented by their librarian, recent news articles on the internet and other printed news sources. Besides these specific trades, students are also required to do at least four other weekly trades. They report their transactions periodically and then, at the end of the semester, they write a final report summarizing their trades, their holding period returns, and their reasons for selecting specific assets. The forms as well as the directions for students that are provided in this paper can be used in any investments-related class. In the final section, we explain students' common mistakes when completing this assignment.

\section{Literature review}

In order to familiarize their students with different types of investments, several universities and colleges have started using a Student Managed Investment Fund (SMIF). Several papers including D'Souza and Johnson (2019), Charlton, Earl and Stevens (2015), Lawrence (2008), Clinebell and Murphy (2016), Kahl (1997), Heck et al. (2011), and Macy (2010) have explored SMIFs in a college setting. McInerny (2003) examined SMIF at the high school level.

Also, professors around the world have been using stock simulation programs like Stock-Trak in their classes, again with the purpose of teaching their students the different types of investments in a practical manner. There are several studies that examine how games and simulations used in business or economics classes increase students' knowledge and interest-levels. Cebula and Toma (2002) find that these types of applications have a positive impact on students. Harter and Harter (2010) examine financial literacy among high school students and show that stock market simulations can significantly increase financial literacy among these students. Moffit, Skull and McKinney (2010) show that students' knowledge- and interest-levels improve after completing an equity trading game.

Felton, Gibson and Sanbonmatsu (2004) use Stock-Trak to examine how gender and optimism affect students' risk aversion. They show that more optimistic students and male students tend to make riskier investments than others. He et al. (2008) use Stock-Trak to compare face-to-face and computer-mediated communication teams. They show that while face to face team members tend to feel greater levels of trust, affiliation and satisfaction in their team collaboration process, computer-mediated communication teams eventually outperform them. Nguyen and Luthar (2015) show that Stock-Trak has helped their students in two ways: They have learned how to invest but they have also started following news delivered by major financial medias. Lee et al. (2013) have used Stock-Trak to "determine the behavioral factors that males and females exhibit when making investment decisions". They show that "males and females exhibit different behavioral biases and these behavioral biases can ultimately affect investment performance". Guo, Bayer, and Blair (2013) have explored the use of Stock-Trak in Executive MBA education. Wann and Lobo (2010) have used Stock-Trak in their classes and show that male students are more overconfident than female students as evidenced by their more frequent and larger trades. They show that male students are less risk-averse than female students as evidenced by their more frequent short sales and derivatives transactions compared to females. The authors also show that the returns for both groups were similar. Willey, Edwards and Gondhalekar (2008) show that a student's current scores on exams, cases and reports as well as his/her age are the strongest predictors of performance in online simulation. Girard, Pondillo, Proctor (2005) show how Performance Attribution Analysis can be integrated into a Stock-Trak simulation used in a class. Welch (2014) demonstrates that less complex assignments in simulation increases students' interest and participation in the game.

While all of these studies discuss how Stock-Trak can be implemented and/or the benefits associated with such an exercise, in this current study, we look from a different angle and focus on the common mistakes that students make when playing an in-class game. We examine the types of mistakes that our undergraduate level 'investments' students make when using Stock-Trak, over the 2014-2017 period. In the next section, we explain our methodology and research methods. 


\section{Methodology and research methods}

First, we create a Stock-Trak assignment. In this assignment, students are asked to make certain trades using stocks, mutual funds, market index funds, T-bills, Treasury/corporate/municipal notes or bonds, and call and put options. In addition to these trades on these specific assets, students are also required to make at least four weekly trades. In order to teach them different aspects of 'investing', the assignment also forces them to take both long and short positions in stocks and to purchase stocks on margin.

Students report their transactions periodically, and then, at the end of the semester, they write a final report summarizing their trades, their holding period returns, and their reasons for selecting specific assets. The forms as well as the directions for students are provided in this paper. There are three tables that they need to complete.

Besides creating this specific assignment which may be helpful to professors around the world, in this paper, as mentioned previously, we also look into the common mistakes that students make when completing this assignment. When we use this assignment at our college, we find that students make a wide array of mistakes. These mistakes include ignoring the transaction costs and ignoring the dividends in their calculations. We also find that students are not good with financial ratios. They cannot decide whether having a higher or a lower ratio (like liquidity ratio, turnover ratio, etc.) is good for a firm. Students also cannot determine the initial investment amount with a margin purchase. Some of them mistakenly include the borrowed amount in the initial investment. They also cannot differentiate an in-the-money option from an out of-the-money option. They do other mistakes as well. In this paper, we present our findings on these 'common mistakes' in detail.

We are hoping that this study will help professors around the world in two ways: First, they can use this specific assignment (with all the corresponding forms and directions) in their investments-related class. Second, they can look at these common mistakes that students tend to make, and try to teach their students these specific points. Doing this should help their students to be more successful overall.

\section{The assignment}

The assignment that we had created and used in our undergraduate basic investment classes is shown below. All of the forms and directions for students are presented. After this section, we will present the 'common mistakes' that our students tend to make when completing this assignment.

Fin 3633 - Stock-Trak Investment Game:

Writing Assignment \#1

Trade Execution, Stock Analysis and Option Performance

(Purchase by SEPT 5 and Report Due on OCT 2)

\section{A. Trades (10 points)}

1. As a professional team of financial analysts, you will be asked to pick 10 stocks, 4 mutual funds, 4 market Index funds and four Treasuries or bonds, two calls and 2 puts listed either on the New York Stock Exchange, the American Exchange, NASDAQ or any other international exchanges outside the US for your client. You should use Research Insight, databases presented by the librarian, recent news articles on the internet or any other printed news sources to make your selection.

a. Long at least 100 shares of these 4 stocks that you believe are most likely to increase in value during the next three months. You can use market order, limit order or stop order to purchase the stock. Limit orders allow you to buy or sell a set amount of a financial instrument at a specified price. However, if the price does not meet the limit price the order may not be executed. A stop order will become a market order once the stock price reaches the stop price. It can be used to stop loss. However, you may end up buying below the stop price when the market crashes.

b. Short sell 4 stocks that are likely to decrease in value. Short selling a stock means selling a stock that you do not own. When you short sell a stock, the stock will come from a brokerage firm. The proceeds from the sale are credited to your account. You can 'cover' the short by buying the stocks short and returning them to your broker. You will make a profit/loss if you can buy back the stock at the lower/higher price. 
Note that you can only short sell a stock when it is at or above the last price and your order can only be executed at the last price if it was an up-tick. Keep an eye on this position; you may want to cover your position when the stock is not heading south.

c. Purchase at least two stocks on margin. Generally, you will need to open a margin account to trade on margin. In order for you to purchase on margin in Stock-Trak, you will have to invest more than your initial investment. Amount used above your initial wealth will be the amount you borrow. The computer will automatically do the borrowing for you. You cannot borrow more than $50 \%$ of the price of the stock. There will be interests charged to the account to pay for the borrowing. Margin calls can be triggered when you borrowed too much and then you may be forced to sell assets to pay to bring the margin up.

2. Purchase at least 2 call and 2 put option contracts (right to buy 100 shares of stock) on the stocks that you long. The option contract that you buy should have the following characteristics:

a. Slightly out-of-the-money for call, i.e. the exercise or strike price of the option is slightly higher than current stock price. The opposite for PUT

b. With an expiration date beyond 2 months.

To purchase an out-of-money call (i.e. strike price > current price) with expiration date beyond three months:

Step 1: Find the stock symbol of the company using QUOTE and then choose SYMBOL LOOKUP on the top panel of Stock-Trak.

Step 2: Write down the last traded price of that company, e.g. AAPL at \$48.17 on Jan 19.

Step 3: Choose OPTION CHAIN. Find AAPL call options with expiration date beyond 2 months with strike price > current price, e.g. In March 19, ABT1119C49 call has a strike price of $\$ 49$ which is greater than \$48.17. Expiration date March 19 is 2 months from Jan 19. For your assignment, the expiration date of the call should be at least beyond April 1 .

Step 4: Go to Trade, enter the option symbol e.g. ABT1119C49, the quantity (number of contract).

**** When you buy option, make sure you follow the format of options in Stock-Trak. Other resources have different ways to code the options. A lot of options are thinly traded and so may not be available for trading. If the option you have chosen is not traded, you may want to find another one with a different expiration date and exercise price or just choose another company's option.

While you may want to lightly read some basic sections from your textbook on options, you do not need to thoroughly understand options at this time. Just buy some. We will explain it later when we go through that chapter.

You may also purchase options on the other stocks if you would like to, but you are not required to use the information regarding those options contract in the writing assignment.

*** You are required to hold the stock that has the out-of-money options during the whole trading period. Make sure you track the changes of option prices as your stock fluctuates on a daily basis. You will need to use this information in your write-up. We will need that information about that stock and options in this and later assignment.

3. Purchase a 3-month Treasury bill and 3 other Bonds available on Stock-Trak.

4. Purchase at least 100 shares of 4 Mutual Fund or index funds. Two of which must be market index funds that represent the overall market. The third one has to represent an international market.

Please note that the trades listed above are required trades. These transactions can be counted towards the weekly four-trade requirement. Please use table 1 to submit a summary of trades by September 5 . 
Table 1. Summary of Trades

\begin{tabular}{|c|c|c|c|c|}
\hline Date of Purchase of Best Performing Stocks & Stock Name & Purchase Price & Option Name & Option Prices \\
\hline \multicolumn{5}{|l|}{ 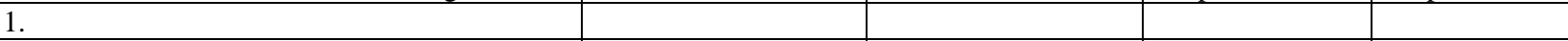 } \\
\hline \multicolumn{5}{|l|}{2.} \\
\hline \multicolumn{5}{|l|}{3.} \\
\hline \multicolumn{5}{|l|}{4} \\
\hline Date of Short Selling Stocks & Stock Name & Short Sell Price & & \\
\hline \multicolumn{5}{|l|}{1} \\
\hline \multicolumn{5}{|l|}{2.} \\
\hline \multicolumn{5}{|l|}{3.} \\
\hline \multicolumn{5}{|l|}{4.} \\
\hline Date of Stocks Purchased on Margin & Stock Name & Purchase Price & & \\
\hline \multicolumn{5}{|l|}{1.} \\
\hline \multicolumn{5}{|l|}{2.} \\
\hline Date of Calls/Puts Purchased & Stock Name & Purchase Price & Exercise Price & Maturity Date \\
\hline 1. $\quad$ Call & & & & \\
\hline \multicolumn{5}{|l|}{ 2. Call } \\
\hline Put & & & & \\
\hline $2 . \quad$ Put & & & & \\
\hline \multicolumn{5}{|l|}{ Treasuries or Bonds } \\
\hline 1. $\quad$ Treasury Bills & & & & \\
\hline \multicolumn{5}{|l|}{$\begin{array}{l}2 . \quad \text { Treasury/Municipal/Corporate } \\
\text { Notes/Bonds }\end{array}$} \\
\hline \multicolumn{5}{|l|}{$\begin{array}{l}\text { 3. Treasury/Municipal/Corporate } \\
\text { Notes/Bonds }\end{array}$} \\
\hline \multicolumn{5}{|l|}{$\begin{array}{l}\text { 4. Treasury/Municipal/Corporate } \\
\text { Notes/Bonds }\end{array}$} \\
\hline Mutual Funds and Market Index Funds & Fund Name & Purchase Price & Symbols & \\
\hline \multicolumn{5}{|l|}{ 1. Mutual Funds } \\
\hline \multicolumn{5}{|l|}{ 2. International MKT Index Funds } \\
\hline \multicolumn{5}{|l|}{ 3. Market Index Funds } \\
\hline 4. Market Index Funds & & & & \\
\hline
\end{tabular}

Source: Authors' own work in the Fin3633-Investments class at Northeastern State University.

\section{B. Write-up}

\section{Part I - Stock and Bond Purchases}

In your write-up, you are required to write about three stocks: your best performing stock, a stock that you buy on margin and a stock that you short sell. For each of the stocks, please include the followings sections in your report:

i.e. Stock 1 (best performing stock)

Stock 2 (short sell stock)

Stock 3 (margin stock)

Bond (Corporate)

\section{SECTION A: Basic Stock Information}

Company: name of the company (stock symbol)

Purchase Price: \$xx.xx

Current Price: \$yy.yy

Dividends Paid: \$z.z

Quantity traded: a number

Transaction costs per trade and total costs (buy and sell = cost for 2 trades): $\$ \$$

Cover price (price at which stocks are purchased to cover the short) \$uu.uu in case of short selling

Short sale price (price at which stocks are sold) \$ww.ww in case of short selling 
SocioEconomic Challenges, Volume 4, Issue 1, 2020

ISSN (print) - 2520-6621, ISSN (online) - 2520-6214

Margin: Equity invested/ (current price of stocks times shares bought)

Note: Current price is not equal to the purchase price of the stock.

Interest charged (in \% and \$) in case of margin or short sales.

Holding Period Return (\%) (show me your step-by-step calculation! If you have forgotten, you may need to refer to chapter 5 for the formula for holding period return calculation). When we talk about return in finance, we always use percentage return unless otherwise specified.

** For the stock that you purchase on margin, explain how your margin trading affects your holding period return in percentage. Discuss and show what the returns would be with and without the margin.

\section{SECTION B: Stock/Bond Analysis}

a. Business Description: Briefly describe the business of each of the companies that you selected. You will need a paragraph on this.

b. Stock Performance: Discuss the past performance of the stock

- Show 2 charts of prices over time: one for the Long term (> 1year) and another on for the short term $(<1$ year)

- Discuss briefly both the overall long term and short term performance.

a. Significant News and Events and its Impact on Stock Performance:

i. Provide at least two recent news articles or other printed research information about significant events happened to this company.

ii. Show me how the stock price changes in response to each of the new story. You will need to show the price one day before the event, the price of the event date and one to 2 days after the event

iii. Explain the reaction of stock price to the event, i.e. why do you think the stock goes up or down due to the event.

a. Reasons for your Choice of Best Performing and Short Selling Stock: see next page for the format of this part.

Explain the rationale for your choice of the best performer, short selling stock and its competitor.

i. Show the details of at least eight decision criteria such as financial ratios (e.g. profitability ratio, efficiency ratio, liquidity ratio and leverage ratios), management and riskiness (beta, standard deviation), etc. of your company, one comparable competitor and the industry average. Use those criteria that have competitor and industry information. It will take you some time to find the industry and competitor's data. So make sure you read the lecture notes of the librarian's talk as to where you can find this information. You should get your group mates' notes if you did not write that down.

ii. Make sure you define what those criteria are (show the formula)

iii. Discuss what your criteria measure (e.g. liquidity, profitability...). Why does it worth considering?

iv. How have your stocks been performing relative to the competitors and the industry?

v. You will have to interpret the data that you provide above, i.e. how well is your company doing compared to the competitor and the industry. The higher the number is better or lower the number is better

vi. Give at least two reasons for your choice of competitor.

vii. Give at least three other reasons (in addition to the financials) that it is the best stocks for purchase or for sale relative to its comparable competitors within the same industry

viii.List at least two concerns that you have for this stock and show how the company addresses those concerns that you mention above for the best performing stock. Show the company strategy addresses/not addresses your concerns.

You may consider using table 2 to summarize your reasons for your selection of stocks. 
Table 2. Reasons for Choice of Best Performing Stocks

\begin{tabular}{|c|c|c|c|c|c|c|c|c|c|}
\hline 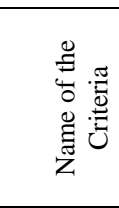 & 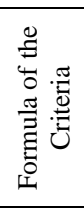 & 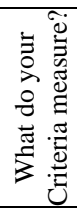 & 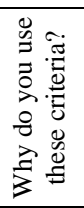 & 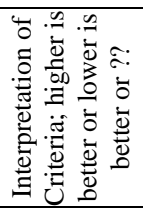 & 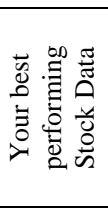 & 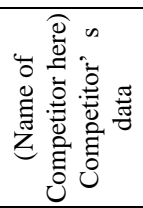 & 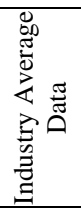 & 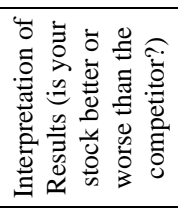 & 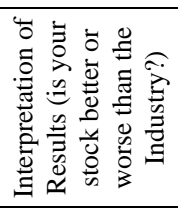 \\
\hline \multicolumn{10}{|c|}{ I. Decision Criteria (16 points) } \\
\hline \multicolumn{10}{|c|}{\begin{tabular}{l|l|l}
1. & & \\
\end{tabular}} \\
\hline \multicolumn{10}{|l|}{2.} \\
\hline \multicolumn{10}{|l|}{3.} \\
\hline \multicolumn{10}{|l|}{4.} \\
\hline \multicolumn{10}{|l|}{5.} \\
\hline \multicolumn{10}{|l|}{6.} \\
\hline \multicolumn{10}{|l|}{7.} \\
\hline 8. & & & & & & & & & \\
\hline
\end{tabular}

Source: Authors' own work in the Fin3633-Investments class at Northeastern State University.

You need to fill out table 3 regarding your choice of the competitor and the stock

Table 3. Choice of the Best Performing Stock (section II-IV)

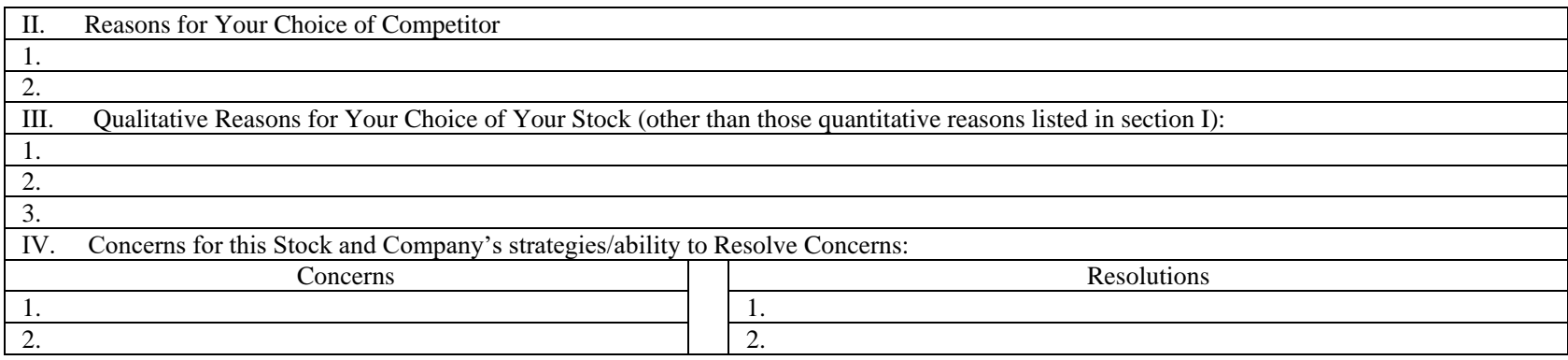

Source: Authors' own work in the Fin3633-Investments class at Northeastern State University.

\section{Part II - Mutual Fund Purchases}

Based on a goal of your choice, you are required to purchase one mutual fund out of two funds that you consider. There are no specific requirements regarding the number of shares you must purchase. The primary objective of this writing assignment is to explain why you have chosen the particular mutual fund. Be sure that this fund appears in your portfolio when the assignment is handed in.

For each of the two mutual funds, you are to contact the management company and seek their opinion regarding the appropriateness of the fund you have chosen from their company. Thus, disclose your goal and your choice of fund from their company and see what they think. Create a dialog with the customer service representative and develop an opinion of the quality of the customer service organization. Be sure to find out what you need to do in order to open up an account and find out what mechanisms they may have for making investments and transferring funds. Either have the company send you a prospectus or read through the online prospectus.

Your write-up should follow the guidelines listed below.

\section{Goal and Objectives:}

State your overall investment goal. The mutual fund you are selecting will be part of that portfolio. In your goal statement, include:

a. Your goal

b. Estimate for the time horizon and

b. Your risk tolerance.

For example: 
- Goal of the portfolio is to accumulate funds for retirement in 40 years. The investor is willing to take slightly above average risk.

- Goal of the portfolio is to generate funds for kid=s education needed in 12 years. The investor is seeking below average risk.

- Goal of the portfolio is to create a pool of funds out of which a vacation home will be built on a secluded lake in Montana over the next 25 years. The investor is willing to accept average risk.

2. Share with me your opinion of the followings for each of the funds:

a. Customer service system (web site in most cases) and

b. Prospectuses (Check it on-line).

Were they easy to use and read, informative, and appropriate for your level of knowledge? What do you like about the service/literature and dislike about those? Do not include the prospectuses with your report.

3. After consultations with the two mutual fund companies, you are to choose one of the funds to purchase. Total 30 points for the contents of the table

Selection Criteria: Choose at least 8 major characteristics that you will use as the criteria for fund selection. You need to provide the data to support your discussion. Rank the criteria in order of importance. Explain your ranking. The industry and specific fund criteria should include characteristics such as performance, rankings by analysts, returns, standard deviation, beta, expense ratio, management tenure, load or no-load fund, the appropriateness of the Beta verses your client's risk preference, and any other financial data you encounter. It's all about communication skills. The report reader should not need to do any analysis.

4. Compare the two funds based on those criteria and choose the one that you think is best.

10 points total for your final analysis of your choice. Discuss the rationale for the final choice thoroughly. Your analysis should include:

a. Analyses of the global, economic environment and

b. Industry environments expected during your investment time horizon.

c. Technical Analysis employed.

d. Identify the risk characteristics of the fund (i.e., Beta, historical trading range, etc.). and

e. Justify your investment recommendation based on your goal, empirical evidence of the past performance and analysis of future performance.

You may consider summarizing your selection criteria in table 4 .

Table 4. Summary of the Comparison of Mutual Funds

\begin{tabular}{|c|c|c|c|c|c|c|c|c|}
\hline Criteria & Fund 1 & Fund 2 & $\begin{array}{l}\text { Definition of } \\
\text { the variable }\end{array}$ & $\begin{array}{l}\text { Reasons for } \\
\text { the selection } \\
\text { of that } \\
\text { particular } \\
\text { criterion. }\end{array}$ & $\begin{array}{c}\text { Rank } \\
\text { based on } \\
\text { criteria }\end{array}$ & $\begin{array}{l}\text { Explain your } \\
\text { ranking }\end{array}$ & $\begin{array}{l}\text { Interpret the } \\
\text { criteria: is } \\
\text { higher/ } \\
\text { lower better? } \\
\text { Which fund } \\
\text { is better? }\end{array}$ & $\begin{array}{l}\text { Analyze the } \\
\text { difference } \\
\text { between the funds } \\
\text { related to that } \\
\text { characteristic. }\end{array}$ \\
\hline 1.Load & data & data & & & & & & \\
\hline 2. Expense ratio & data & data & & & & & & \\
\hline . & & & & & & & & \\
\hline 6. & data & data & & & & & & \\
\hline 7. & & & & & & & & \\
\hline 8. & & & & & & & & \\
\hline
\end{tabular}

Notes: *** Use the last trading prices on the last Friday prior to the report submission as the selling prices of the stocks, bonds, mutual funds and options.

Source: Authors' own work in the Fin3633-Investments class at Northeastern State University. 
You are a professional team providing this investment information to your clients and helping them with their portfolios. Please submit this in a report format. Report must be typed and handed in on the due dates in class. Please consult the writing lab if you have questions about professional business writing. Your grade will be based on the logic of your pick, your calculation, research and presentation of information as well as the fulfillment of the investment requirement.

You must have your stocks and option purchased by SEPT 5. The due date for this assignment is Oct 2 - 5:30 p.m. Last day for trading data is SEPT 18. Keep electronic copies of all of your transactions.

Please also refer to your syllabus for additional investment requirement for the whole trading period. Note a minimum of four trades are required for each week.

Your grade will be based on the rubric given to you as well as the followings:

a. Fulfillment of the investment requirement prior to or on due date.

b. Fulfillment of the writing and calculation requirement (including steps)

c. Presentation of your research and analysis (logic of your choice of stock)

d. Demonstration of professional style and format (APA style) such as:

i. Inclusion of executive summary, introduction and conclusion of the whole report.

ii. Referencing of materials (References)

iii. Consistency in formats and writing.

iv. Continuality of ideas especially on the transition of sections

v. Page numbering

vi. Table of contents

vii. Spell check

viii. Grammar check

ix. Professional presentation of information.

Please note that the above check list is not intended to be comprehensive, but it will give you a good idea on how the report is being evaluated. You are required to submit a note indicating that your report has been reviewed by the writing center.

Please refer to the APA guide (under course document on Blackboard) for the appropriate style for writing your report. The APA Style web site is http://www.apastyle.org/. The NSUBA writing center is located at the library. Call Ms. Monique Idoux at 918-449-6519 for more information. Their web site address is: http://www.wcba.nsuok.edu. To view 'PDF' documents referenced on this APA Style guideline page, you need Adobe Acrobat Reader. To download the free Acrobat Reader, go to http://get.adobe.com/reader/.

\section{Results}

In terms of being able to make all the trades, about $15-20 \%$ of the students have not completed the trades requirement. Despite the popularity of web applications, a small group of students are not familiarized with pull-down menus and investment web interfaces. About half of the students are not familiarized with some or all of the terms and concepts of 'ticket symbol', 'short selling', 'market index funds', and 'Treasury bills', 'options' 'calls' and 'puts', 'in-the-money' and 'out-of-money'. They have trouble following the step-by-step instructions in the assignment to buy options. For stock and other mutual fund selection, some students are also overwhelmed by the many five-star-funds and top picks of stocks from the screeners of Morning Star, Net Advantage and Mergent. In addition to options, market index funds, treasury bills and international mutual funds are popular missing trades. Mergent has international databases for foreign stocks. Support from the reference librarian after going through professional databases in class is crucial. Students tend to forget where to access various types of information. 
In terms of return calculations, students generally have problems including all elements in the return calculations such as dividends paid, transaction costs and any interests on loan. Some of them may reverse the signs of cash inflows versus outflows of the short sale stock. For the return of the stock on margin, students did not take into account the amount of borrowing when determining the initial investment. The risk averse students may be tempted to take capital gains whenever they reach the profit level. Complications arise when a portion of their holdings is being sold multiple times during the holding period. Students then have to prorate their returns based on the holding periods. For annualized returns, students usually present the annual percentage rate instead of the effective annual rate of return, which takes into account the compounding effect.

For the parts related to stock reaction to significant company events, some students do not see the announcement effect of events when the news of the event is previously released or when the announcement returns are crowded by multiple events during the measurement period. However, most students are able to find many isolated significant announcements and interpret reasonably well the stock reactions to the events.

For the rationale for security selection, most students are able to pull various risk measures, market price and earnings ratios, profitability, leverage, liquidity and efficiency ratios to support their selection. The interpretation of those financial ratios and risk measures can be a challenge for some students. First of all, higher does not always mean better for some of the ratios, e.g. days account receivable outstanding. High liquidity also comes with an opportunity cost. Second, finding a benchmark is crucial for a valid comparison. Quite a number of students find it challenging to locate industry data on those financial ratios. When finding competitor and industry information, Mergent does have a more manageable list of competitors than Net Advantage. The report builder enables students to download and manipulate financial data of the target firm and its competitors in excel. Net Advantage also have 'Competitors' and 'Industry Information'. It is useful for understanding the business environment, its opportunities and threats. Users will need to search for the company, and at the profile page, 'Competitors' and 'Industry Information' are parts of the selections available on the menu on the left column of the page.

As for the qualitative analysis, most students are able to find opportunities and threats from analyzing news articles and going through the analyst reports from Morning Star and other databases. Some students have difficulties in finding out how their companies address the potential threats. Most of the analyst reports have their version of addressing those issues.

When looking at the 'executive summary', students usually cannot differentiate between 'abstract' and 'conclusion'. 'Abstract' presents a condensed overview of the report highlighting all major issues explored and their proposed results and actions whereas 'Conclusion' evaluates the results, methodology and findings of the report.

Another problem is the students' compliance with the APA style, such as referencing sources within the report as well as in the bibliography section. When referencing a figure related to the asset's long and short term performance within the report, students usually refer the figure as 'the figure above' or 'below' instead of actually mentioning the figure number. They tend not to capitalize the first letter in the word 'Figure'. Also, they do not capitalize the existing title and or the description of the graph (i.e. only capitalize the first word in the sentence). Book titles and journal titles are supposed to be in italics and 'title cased'. That means all major words of the title have to be capitalized.

\section{Conclusions, discussion and recommendations}

In this study, we present how undergraduate-level investments students can be engaged in portfolio management. In this application, students invest in stocks (long or short), mutual funds, market index funds, Treasury bills, Treasury/corporate/municipal notes or bonds, and call and put options. They are required to take long and short positions in stocks and purchase at least two stocks on margin. Students use different databases, news articles and other printed sources when making their selections. Besides these specific trades, students are also required to do at least four other weekly trades. They report their transactions periodically and then, at the end of the semester, they write a final report summarizing their trades, their holding period returns, and their reasons for selecting specific assets.

We have used this assignment in several of our sections at our college. We have found that, when completing this assignment, students tend to make some common mistakes. These mistakes include ignoring the transaction costs and ignoring the dividends in their calculations. We also find that students are not good with 
financial ratios. They cannot decide whether having a higher or a lower ratio (like liquidity ratio, turnover ratio, etc.) is good for a firm. Students also cannot determine the initial investment amount with a margin purchase. Some of them mistakenly include the borrowed amount in the initial investment. They also cannot differentiate an in-the-money option from an out of-the-money option. They do other mistakes as well, as shown in this paper.

We are hoping that this assignment along with its forms and directions will help professors around the world who teach investments-related classes. We are also hoping that professors improve their classes by taking note of these 'common mistakes' that students tend to make and taking precautions beforehand. We recommend professors to focus more on the areas that students seem to fail as explained in this paper.

\section{References}

1. Cebula, R. \& Toma, M. (2002). The effect of classroom games on student learning and instructor evaluations, Journal of Economics and Finance Education, 1(2), Article 1. https://mpra.ub.unimuenchen.de/55404/1/MPRA_paper_55404.pdf

2. Charlton Jr, W. T., Earl, J., \& Stevens, J. J. (2015). Expanding management in student managed investment funds. Journal of Financial Education, 1-23. https://www.jstor.org/stable/24573676?seq=1

3. Clinebell, J., \& Murphy, J. (2016). Student managed investment funds: the perspectives of alumni. Journal of Financial Education, 42(3-4), 304-312. https://www.jstor.org/stable/90001155?seq=1

4. D'Souza, F. P., \& Johnson, M. A. (2019). Structuring an Endowment-Allocated Student Managed Fund Course. Business Education \& Accreditation, 11(1), 51-60. http://www.theibfr2.com/RePEc/ibf/beaccr/bea-v11n1-2019/BEA-V11N1-2019-4.pdf

5. Felton, J., Gibson, B. \& Sanbonmatsu, D. M. (2004). Preference for risk in investing as a function of trait optimism and gender, The Journal of Behavioral Finance, 4(1), 33-40. https://www.researchgate.net/profile/James_Felton/publication/228224426_Preference_for_Risk_in_Inv esting_as_a_Function_of_Trait_Optimism_and_Gender/links/0912f512e8312b474e000000.pdf

6. Girard, E., Pondillo, A., \& Proctor, R. (2005). Conducting Performance Attribution Analysis in the Classroom Using Real Market Data. Journal of Financial Education, 57-76. https://www.researchgate.net/profile/Eric_Girard/publication/237439098_Conducting_Performance_Att ribution_Analysis_in_the_Classroom_using_Real_Market_Data/links/0c960529cdb54617b4000000.pdf

7. Guo, W., Bayer, C., \& Blair, D. (2013). Adapting STOCK-TRAK ${ }^{\circledR}$ in Executive MBA Investment $\begin{array}{lllll}\text { Education. Journal of Executive } & \text { Education, } & 1(2), & 4 .\end{array}$ https://digitalcommons.kennesaw.edu/cgi/viewcontent.cgi?article $=1083 \&$ context $=$ jee

8. Harter, C. \& Harter, J. F. R. (2010). Is financial literacy improved by participating in a stock market game? $\begin{array}{lllll}\text { Journal for Economic } & \text { Educators, } & \text { 10(1), }\end{array}$ https://libjournals.mtsu.edu/index.php/jfee/article/view/1459

9. He, F., Pearson, J., Mykytyn, P. P. \& Sheng, Y. (2008), Risky Group Decision Making: A Comparative Analysis of FTF and CMC Teams in Stock-Trak Investment Simulations, AMCIS 2008 Proceedings, 239. https://pdfs.semanticscholar.org/7290/5fee4fb3ac6b7f9aad77da6902896365f80a.pdf

10. Heck, J. L., Ammermann, P. A., Runyon, L. R., \& Conceicao, R. (2011). A new quantitative approach for the management of a student-managed investment fund. Managerial Finance. https://www.emerald.com/insight/content/doi/10.1108/03074351111140261/full/html

11. Kahl, D. R. (1997). The challenges and opportunities of student-managed investment funds at metropolitan universities. Financial Services Review, 6(3), 197-200. http://citeseerx.ist.psu.edu/viewdoc/download?doi=10.1.1.392.3648\&rep=rep1\&type=pdf

12. Lawrence, E. C. (2008). Student managed investment funds: an international perspective. Journal of Applied Finance (Formerly Financial Practice and Education), 18(2). https://papers.ssrn.com/sol3/papers.cfm?abstract_id=2698650

13. Lee, K., Miller, S., Velasquez, N., \& Wann, C. (2013). The effect of investor bias and gender on portfolio performance and risk. The International Journal of Business and Finance Research, 7(1), 1-16. http://www.theibfr2.com/RePEc/ibf/ijbfre/ijbfr-v7n1-2013/IJBFR-V7N1-2013-1.pdf

14. Macy, A. (2010). Student-managed investment funds: a framework for regional schools. Academy of Educational Leadership Journal, 14, 47. https://www.abacademies.org/special-issues/special-issuespdfs/aelj-vol-14-special-issue-2010.pdf\#page $=53$ 
15. McLnerny, P. M. (2003). The student-managed investment fund at the high school level. The Clearing House, $76(5)$ 252-254. https://www.tandfonline.com/doi/abs/10.1080/00098650309602014?journalCode=vtch20

16. Moffit, T., C. Stull, \& McKinney, H. (2010). Learning through equity trading simulation, American Journal of Business Education, 3(2). https://www.clutejournals.com/index.php/AJBE/article/view/386

17. Nguyen, T., \& Luthar, V. K. (2015). Using Stock Trak Simulation in Finance Courses. https://digitalcommons.georgiasouthern.edu/sotlcommons/SoTL/2015/14/

18. Wann, C. R., \& Lobo, B. J. (2010). Gender-based trading: evidence from a classroom experiment. Journal of Economics and Finance Education, 9(2), 54-61. https://www.economicsfinance.org/jefe/econ/WannLobo.Economics.Vol9(2).pdf

19. Welch, S. (2014). Market Simulation Games for Undergraduate Investments Courses: Simple or Complicated? https://digitalcommons.csbsju.edu/cgi/viewcontent.cgi?article=1008\&context=acct_pubs

20. Willey, T., Edwards, S., \& Gondhalekar, V. (2008). Predictors of performance in an online financial management simulation. Journal of Business Case Studies (JBCS), 4(6), 35-42. https://www.clutejournals.com/index.php/JBCS/article/view/4786 